
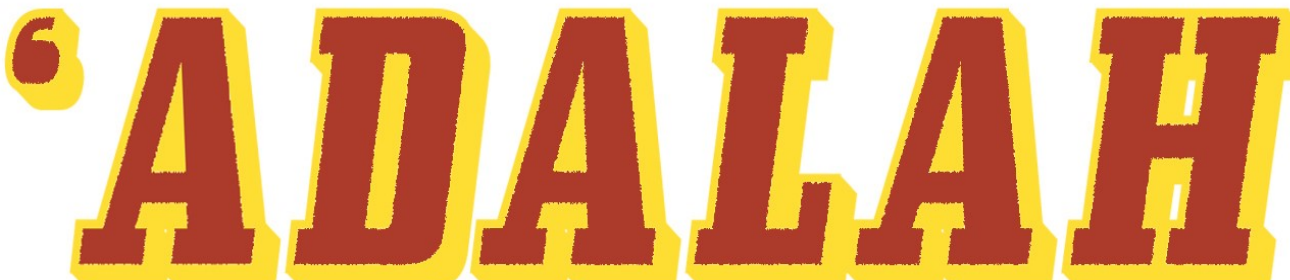

ADALAH : Buletin Hukum \&

Keadilan

@adalahuinjkt

Buletin Hukum \& Keadilan

\title{
Batasan Kebebasan Beragama
}

\author{
Latipah* $^{*}$
}

Negara Indonesia sebagai Negara yang berdasarkan Pancasila menempatkan agama pada kedudukan penting dan mempunyai peranan serta menjadi sasaran dalam pembangunan. Dengan demikian kepentingan agama perlu memperoleh perlindungan hukum, sehingga sangat wajar apabila dalam KUHP terdapat pengaturan terhadap tindak pidana agama.

Perlindungan kebebasan beragama termaktub dalam Undang -Undang Dasar Tahun 1945 pasal 29 ayat (1) dan (2), akan tetapi pemerintah belum menentukan agama dan kepercayaan apa saja yang diakui secara sah. Walaupun pada akhirnya putusan Presiden di era Gusdur menetapkan enam agama yang diakui secara sah di Indonesia, tetapi status agama lainnya belum diakomodir secara merata.

Hukum pidana Indonesia mengatur segala aspek kehidupan masyarakatnya, karena berkaitan dengan fungsinya sebagai kontrol sosial maupun rekayasa sosial. Adanya pengaturan tindak pidana agama adalah amanat konstitusi. Hadirnya konflik yang bernuansa agama membuat citra Indonesia menjadi keruh di mata dunia, pasalnya negara Indonesia adalah negara yang menjunjung tinggi toleransi dan sangat menghormati

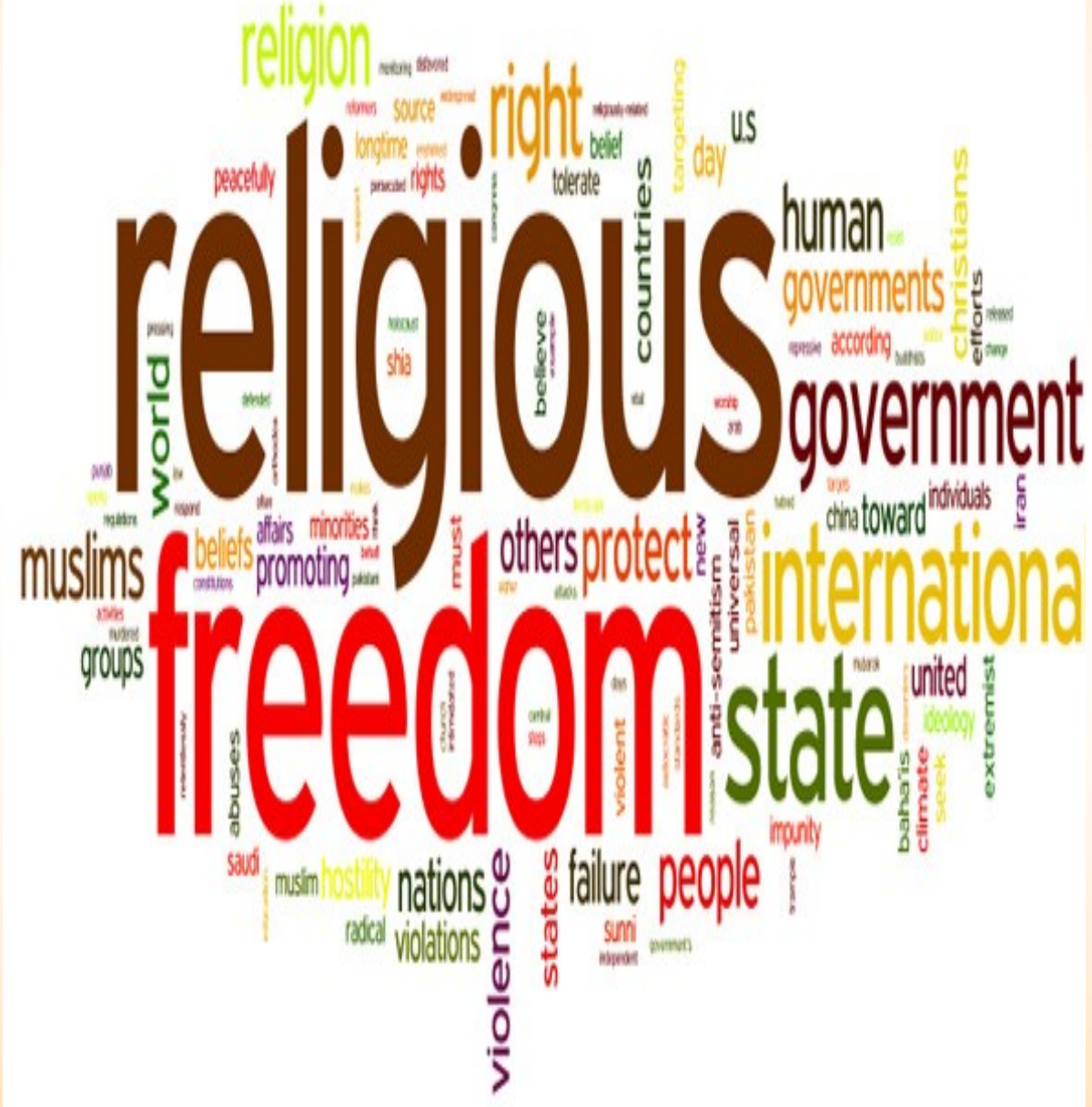

keanekaragaman bangsanya. Bhineka tunggal ika sebagai semboyan yang diagung-agungkan masyarakatnya berbalik dengan hal itu karena fakta yang terjadi adanya sikap intoleransi masyarakat yang kadang kurang memahami akan pluralnya masyarakat Indonesia sebagai realitas sosial.

Pengaturan tindak pidana agama sebagai konsekuensi dari amanat konstitusi, dan munculnya kasus penodaan agama disebabkan banyak faktor, salah satunya adalah peraturaan perundangan yang belum mengakomodir secara tuntas. Disatu sisi kebebasan beragama merupakan hak asasi yang tidak dapat dikurangi dalam keadaan apapun, bahkan setiap orang bebas memilih agama dan beribadat menurut agamanya. Disisi lain 
negara menjamin kemerdekaan memeluk agama, sedangkan pemerintah berkewajiban melindungi masyarakat dalam melaksanakan ajaran agama serta beribadat sepanjang tidak bertentangan dengan peraturan perundang-undangan, tidak mengganggu ketentraman dan ketertiban umum.

Hukum bukanlah tujuan pada dirinya sendiri. Hukum adalah alat bagi manusia, ia merupakan instrumen untuk melayani kebutuhan manusia (Sopyan, 209: 2015). Penetapan presiden Nomor 1 PNPS Tahun 1965 tentang Pencegahan Penyalahgunaan dan/Penodaan Agama. Bertujuan untuk melindungi agama dan praktik beragama yang berkembang di masyarakat dan melindungi setiap keyakinan agama dan praktik yang dilakukan oleh pengikutnya dari penodaan dan kecenderungan berbuat tindak pidana terhadap agama. Penetapan presiden tentang pencegahaan dan penodaan agama kemudian dimasukkan ke dalam KUHP bab V tentang Ketertiban Umum pada pasal 156 dan 156a. Sebetulnya maksud dari dibuatnya pasal tersebut bukan merupakan tindak pidana terhadap agama yang ditujukan, melainkan untuk melindungi kepentingan umum dan ketertiban umum yang terganggu karena adanya pelanggaran terhadap kepentingan umum.

Dalam hal ini negara hanya dapat melindungi hak masyarakatnya dalam forum eksternum, sedangkan perihal internum merupakan kebebasan mutlak yang dimiliki oleh masyarakat itu sendiri. Disinilah letak pentingnya toleransi dalam beragama ketika masyarakat mengedepankan rasa toleransi tanpa ego kemudian hal ini mendukung terciptanya kerukunan dalam beragama. Adapun berbagai polemik terkait penyalahgunaan/penodaan agama seringkali terjadi di negara Indonesia yang realitanya merupakan negara yang multikultural dan plural.

Sejatinya agama bukan hanya berisi perihal perintah dan larangan melainkan berisi pedoman, norma, petunjuk yang baik dan benar, hal yang harus ditinggalkan dan yang harus dilaksanskan. Dalam hal ini agama berperan dalam penyelesaian konflik sosial. Islam sebagai agama mayoritas di Indonesia tentu memiliki celah untuk dapat berkehidupan dengan rukun dan sejahtera, hal ini dibuktikan dengan adanya beberapa ayat Alquran yang berisi tentang toleransi dan kerukunan antar ummat.[]

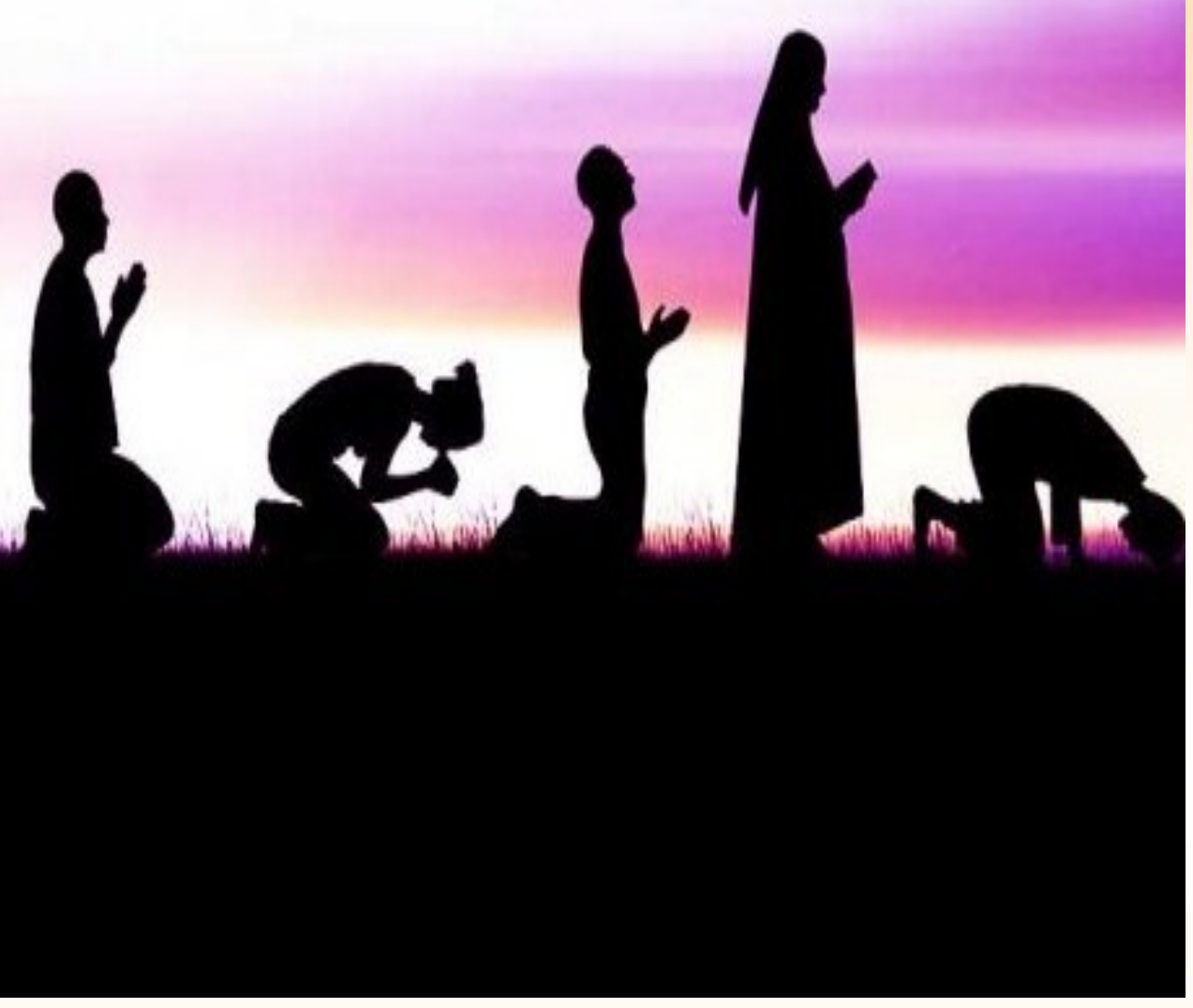

Pustaka acuan

*Penulis adalah anggota Moot Court Community (MCC) FSH UIN Syarif Hidayatullah Jakarta dan anggota Perhimpunan Mahasiswa Hukum Indonesia (PERMAHI).

Sopyan, Yayan, Menyoal Kebebasan Beragama dan Penodaan Agama Di Indonesia (Telaah atas Putusan MK No.140/PUU-VII/2009). Jurnal Cita Hukum. Vol. 3 No. 2 Desember 2015.

Sodikin, Hukum Dan Hak Kebebasan Beragama. Jurnal Cita Hukum, Vol. I No. 2 Desember 2013.

'Adalah; Buletin Hukum dan Keadilan merupakan berkala ilmiah yang diterbitkan oleh Pusat Studi Konstitusi dan Legislasi Nasional (POSKO-LEGNAS), Fakultas Syariah dan Hukum UIN Syarif Hidayatullah Jakarta.

Penasehat: Prof. Dr. H. Abdul Ghani Abdullah, SH., Prof. Dr. H. A Salman Maggalatung, SH., MH. Pemimpin Redaktur: Indra Rahmatullah, Tim Redaktur: Nur Rohim Yunus, Fathuddin, Mara Sutan Rambe, Muhammad Ishar Helmi, Erwin Hikmatiar. Penyunting: Indah Furba, Hasin Abdullah. Setting \& Layout: Siti Anisaul Kamilah. 